Порівняльні результати самостійної роботи студентів експериментальних та контрольних груп

\begin{tabular}{|c|c|c|c|}
\hline \multirow{2}{*}{$\begin{array}{l}\text { № } \\
\Pi / \Pi\end{array}$} & \multirow[t]{2}{*}{ Вид діяльності } & \multicolumn{2}{|c|}{$\begin{array}{c}\text { Результати (загальна кількість } \\
\text { студентів }-87, \mathrm{E} \Gamma-41, \mathrm{~K} \Gamma-46)\end{array}$} \\
\hline & & $\mathrm{E} \Gamma$ & $\mathrm{K} \Gamma$ \\
\hline 1. & \begin{tabular}{|l} 
Планування та поетапна \\
роботи над творчим проектом
\end{tabular} & $85 \%$ & $43 \%$ \\
\hline 2. & Процес створення проекту & $67 \%$ & $50 \%$ \\
\hline 3. & Захист проекту & $100 \%$ & $64 \%$ \\
\hline 4. & $\begin{array}{|lcc|}\text { Обгрунтування ідеї } & \text { та } & \text { технології } \\
\text { виготовлення виробу } & & \\
\end{array}$ & $86 \%$ & $69 \%$ \\
\hline 5. & Презентація виробу (захист) & $100 \%$ & $79 \%$ \\
\hline
\end{tabular}

Як бачимо, за результатами впровадженої методики, ми зафіксували позитивну динаміку розвитку самостійності студентів.

Отже, аналіз результатів нашої роботи підтвердив доцільність використання запропонованих прийомів розвитку самостійності студентів ВНЗ. Можемо зробити висновок, що розвиток професійної самостійності як компонента культури праці відбувається більш успішно, коли у процесі навчально-пізнавальної діяльності перед студентами ставляться такі завдання, які розв'язати відомим способом не вдається, i залишається шлях творчого й самостійного пошуку. Перспективою подальших досліджень убачаємо розроблення спецкурсів з розвитку культури праці під час вивчення окремих дисциплін на технолого-педагогічному факультеті.

\title{
Література
}

1. Блонский П.П. Трудовая школа / П. П. Блонский. - М. : Педагогика, 1976. 249 с. 2. Тхоржевський Д. О. Місце та завдання трудового виховання у системі виховання школярів / Д. О. Тхоржевський // Трудова підготовка в закладах освіти України. - 1995. - № 1. - С. 6-8. 3. Шацкий С. Т. Педагогические сочинения: в 4 т. / С.Т. Шацкий. - Т. 1. -395 с.

УДК 378

Олександр Сушенцев

\section{УМОВИ ФОРМУВАННЯ КОНКУРЕНТОЗДАТНОСТІ МАЙБУТНІХ ЕЛЕКТРОМЕХАНІКІВ У НАВЧАЛЬНО-ВИХОВНОМУ ПРОЦЕСІ ВНЗ}

Сушенцев О. О. Умови формування конкурентоздатності майбутніх електромеханіків у навчально-виховному процесі ВНЗ.

Розглянуто проблему формування конкурентоздатності майбутніх електромеханіків у ВНЗ І-ІІ рівня акредитації. Здійснено теоретичний аналіз науковопедагогічної літератури, присвяченої вивченню педагогічних умов формування конкурентоздатності фахівців в навчально-виховному процесі вищого навчального закладу.

Ключові слова: конкурентоздатність, педагогічні умови, майбутній електромеханік.

Сушенцев А. А. Условия формирования конкурентоспособности будущих электромехаников у навчально-виховному процессе ВУЗА.

Рассмотрена проблема формирования конкурентоспособности будущих 
электромехаников в ВУЗЕ I-II уровня аккредитации. Осуществлен теоретический анализ научно педагогической литературы, посвященной изучению педагогических условий формирования конкурентоспособности специалистов в учебновоспитательном процессе высшего учебного заведения.

Ключевые слова: конкурентоспособность, педагогические условия, будущий электромеханик.

Sushentsev A. A. Conditions of developing competitiveness among future electricians in the educational process of a higher school.

The article deals with the issue as for developing competitiveness among future electricians studying at higher schools of the first and second level of accreditation. The author gives a theoretical analysis into scholarly and pedagogical literature devoted to the study of pedagogical conditions of training competitive specialists in the educational process of a higher school.

Key words: competitiveness, pedagogical conditions, future electrician.

Традиційно головними орієнтирами в освіті було формування знань, умінь, навичок, інформаційних і соціальних умінь (якостей), які забезпечують «готовність до життя», що, у свою чергу, розуміється як здатність пристосування особистості до суспільних обставин. Наразі освіта все більше орієнтується на створення таких технологій і способів впливу на особистість, у яких забезпечується баланс між соціальними й індивідуальними потребами, які, реалізуючи механізм саморозвитку (самовдосконалення, самоосвіти), забезпечують готовність особистості до реалізації власної індивідуальності і зміни суспільства.

Перед сучасним вищим навчальним закладом I-II рівня акредитації стоїть досить важливе завдання - формування в майбутнього фахівця здатності успішно «продати» себе на ринку праці, що вимагає «ефективної організації процесу професійної підготовки, в якій би могли б формуватися такі якості і характеристики майбутнього фахівця», які б забезпечували його конкурентоздатність на ринку праці [3, с. 40]. Незаперечно, що формування конкурентоздатного фахівця можливе лише в певній педагогічній системі за дотримання відповідних педагогічних умов.

Окремі науковці (О. Бойко, Є. Літвіновський, М. Руденко та ін.) педагогічні умови визначають як теоретичні (ціль, завдання, зміст та принципи) і методичні (дидактична технологія, форми та методи, методики) засади навчально-виховного процесу, які забезпечують оптимальне формування конкурентоздатності майбутнього фахівця. Тоді, як В. Андреєв і Ю. Бабанський визначають педагогічні умови як обставини:

- це обставини, за яких компоненти навчального процесу (навчальний предмет, викладання і учіння) представлені в найкращій взаємодії, і яка надає можливість учителю плідно викладати, керувати навчальним процесом, а учням- успішно вчитися (Ю. Бабанський);

- це обставини процесу навчання, які є результатом цілеспрямованого відбору, конструювання й застосування елементів змісту, методів, а також організаційних форм навчання задля досягнення певних дидактичних цілей (В. Андреєв).

Метою статті є обгрунтування сутності умов та визначення таких, що будуть сприяти ефективному формування конкурентоздатності майбутніх електромеханіків у BНЗ I-II рівня акредитації.

Насамперед зазначимо, що умова в розумінні філософів - це те, від чого залежить дещо інше (що зумовлюється), суттєвий компонент комплексу об'єктів 
(речей, їх станів, взаємодій), що виражає відношення предмета до оточуючих його явищ, 3 наявності якого $з$ необхідністю слідує існування даного явища. Сам предмет становить щось зумовлене, а умова - як відносно зовнішнє предмету різноманіття об'єктивного світу. На відміну від причини, яка безпосередньо породжує те чи інше явище або процес, умова складає те середовище, обстановку, у якій останні виникають, існують і розвиваються [8, с. 497-498]. Суголосною цьому є думка, що умови є суттєвим компонентом комплексу об'єктів, з наявності яких 3 необхідністю виходить існування даного явища, і що ця категорія відображає відношення предмета до оточуючих явищ, під педагогічними умовами розуміє обставини процесу навчання і виховання, які є результатом відбору, конструювання і застосування елементів змісту, форм, методів і засобів навчання (О. Штеймарк).

Як свідчить теоретичний аналіз наукових джерел і педагогічної практики, науковці визначають психологічні, організаційні і педагогічні умови розвитку конкурентоздатності студентів навчальних закладів різного рівня акредитації. Заслуговують на увагу дослідження психологів, які визначають психологічні умови, які будуть забезпечувати підвищення рівня конкурентоздатності майбутніх фахівців у процесі їх підготовки у вищому навчальному закладі, якщо використати спеціальну соціально-психологічну програму навчання, яка спрямована на оволодіння студентами: а) знаннями, що розкривають зміст та структуру конкурентоздатності менеджерів; б) методами діагностування основних структурних компонентів конкурентоздатності; в) засобами та прийомами розвитку конкурентоздатності (В. Хапілова).

Поняття «педагогічні умови» прийнято розглядати як сукупність об'єктивних і суб'єктивних чинників, необхідних для забезпечення ефективного функціонування всіх компонентів освітньої системи, зокрема характерною його рисою є те, що воно охоплює елементи всіх складників процесу навчання і виховання: мету, зміст, форми, методи i засоби. Тому до педагогічних можна віднести умови, усвідомлено створювані в педагогічному процесі і спрямовані на формування та реалізацію необхідних якостей цього процесу чи явища. Особливе значення при цьому має визначення повного набору умов, «з яких не можна виключити жодного компонента, не порушивши зумовленості, і до яких не можна додати нічого, що не було б зайвим». Такі умови отримали назву «необхідних і достатніх» [8, с. 498].

Досліджуючи педагогічні умови формування готовності майбутніх учителів економіки до профільного навчання старшокласників, Т. Гуцал стверджує, що педагогічні умови - це структурна оболонка педагогічних технологій чи педагогічних моделей; завдяки педагогічним умовам реалізуються компоненти технології. Варто зауважити, що визначення умов значною мірою залежить від чіткості розуміння кінцевого результату, а саме: від розуміння того, що удосконалення навчання досягається за рахунок реалізації цілої низки умов, їх системи; на певних етапах педагогічні умови можуть виступати як результат, досягнутий в процесі їх реалізації.

Організаційно-педагогічні умови окремі науковці (В. Ільїн) визначають як сукупність зовнішніх обставин освітнього процесу (обставини, середовище, в якому відбувається підготовка учнів) і внутрішніх особливостей особистості студента (спрямованість особистості, іiі здібності та інші психічні особливості), від яких залежить формування професійно значимих якостей особистості. Подібну думку висловлює й В. Андреєв, який говорить про те, що педагогічні умови не можна зводити лише до зовнішніх обставин, до обстановки, до сукупності об'єктів, що здійснюють вплив на процес, оскільки утворенням особистості $\epsilon$ єдність суб'єктивного й об'єктивного, внутрішнього і зовнішнього, суть і явища. Науковець 
вводить поняття «комплекс педагогічних умов», під яким розуміє «сукупність взаємозв'язаних і взаємозумовлених обставин процесу навчання, що є результатом цілеспрямованого відбору, конструювання і вживання елементів змісту, методів або прийомів, а також організаційних форм навчання задля досягнення певної дидактичної мети» [1].

3 огляду на дослідження О. Максимової, педагогічні умови - це сукупність об'єктивних і суб'єктивних чинників, необхідних для забезпечення ефективного функціонування всіх компонентів освітньої системи, що залежить від мети, завдань, змісту, форм і методів цієї системи, тому що особистість - це цілісна система внутрішніх умов, через які проявляються зовнішні дії, підкреслюючи значимість взаємодії об'єктивних і суб'єктивних начал [4, с. 13]. Комплекс конкретних умов розглядуваного явища утворює середовище його протікання, від якої залежить дія законів природи і суспільства. Умова «як одна 3 категорій детермінізму утворює у такий спосіб момент загального в діалектичному взаємозв'язку. Як бачимо, умови розглядаються найчастіше як щось зовнішнє для явища на відміну від більш широкого поняття причини, що передбачає як зовнішні, так $\mathrm{i}$ внутрішні чинники» [8, с. 498].

Наш науковий інтерес викликала думка В. Мезінова, який до основних педагогічних умов, що забезпечують процес формування конкурентоздатності майбутнього фахівця, відносить: організацію освітнього простору i створення середовища, яке стимулює професійне становлення і особистісний розвиток студента; стимулювання у спільній діяльності різнорівневої i різноаспектної взаємодії викладачів і студентів; стимулювання студента до самовдосконалення i самоперетворення в процесі розв'язання професійних завдань, які мають тенденцію до ускладнення; залучення студентів до діяльності, що забезпечує засвоєння норм, принципів i цінностей професійної діяльності; створення оптимального психологічного клімату у студентському колективі; послідовне ускладнення навчальної діяльності - від когнітивно-оцінювального до креативного рівня [5, с. 30].

Дещо іншого підходу дотримується Л. Бодьян, яка в комплексі педагогічних умов формування конкурентоздатності виокремлює такі елементи: відбір і модульне структурування змісту освіти 3 урахуванням особливостей професійної діяльності майбутнього випускника вищого навчального закладу, що сприяє професійній мотивації, самоорганізації і інтегрованому підходу до розв'язання професійних задач, необхідних конкурентоздатному спеціалісту; проектування навчальнокомунікативних ситуацій 3 використанням активних методів i форм навчання 3 формування у студентів конкурентоздатності; послідовне залучення студентів до активної творчої навчально-професійної діяльності, адекватну діяльності конкурентоздатного спеціаліста, на основі інтеграції i наступності професійної підготовки [2, с. 6]. Як бачимо, обидва науковця орієнтуються у визначенні педагогічних умов на особистісно зорієнтоване навчання, в центрі уваги якого $є$ особистість студента. Орієнтація на особистісно орієнтоване навчання у підготовці конкурентоздатних фахівців є однією із важливих умов, яка виявляється в тому, що нині стають важливі не тільки знання, вміння та навички, яких повинен набути студент, а й розкриття його особистісного потенціалу, створення ситуацій вибору і успіху, що дозволяють студенту знайти свою власну траєкторію навчання та професійного розвитку. Водночас, зауважимо, що реалізація особистісно зорієнтованого підходу в сучасному ВНЗ I-II рівня акредитації, як і раніше пов'язана 3 низкою труднощів, які полягають у тому, що до навчального закладу вступають абітурієнти з різним рівнем підготовленості, різними здібностями. Студенти по- 
різному засвоюють матеріал, по-різному ставляться до того, що треба знати, зрозуміти, засвоїти, запам'ятати. Тому навіть саме методично досконале заняття не завжди може бути успішним. Погодимося з відомим психологом Н. Менчинською в тому, що «ефект навчання залежить не тільки від його змісту і методів, але й від індивідуальних особливостей особистості» студента [6, с. 120].

Отже, до педагогічних умов можна віднести ті, які свідомо створюються в освітньому процесі і повинні забезпечувати найбільш ефективне його формування й протікання. Так, організація процесу диференційованої підготовки конкурентоздатного фахівця в системі професійної освіти буде ефективною, якщо: навчально-виховний процес модернізувати в систему інноваційних форм і методів, що активізують пізнавальну i творчу діяльність майбутніх фахівців; поєднувати диференційовані форми навчання як умову підготовки фахівця в системі професійної освіти; використовувати інтеркультурні можливості і особливості ментального освітнього простору, в якому перебувають майбутні фахівці; забезпечити формування професійної компетентності викладача середнього професійного навчального закладу, створивши при цьому необхідні умови для підвищення їх кваліфікації; проводити діагностування особистості і психолого-педагогічного зростання викладача коледжу; розкрити теоретичний інструментарій конкурентоздатності й інтегральних характеристик конкурентоздатної особистості; розробити методи вивчення й розвитку конкурентоздатної особистості в системі середньої професійної освіти (О. Ростовська). Зауважимо, що диференціація жодною мірою не знижує базового рівня професійної підготовки студентів, вона лише забезпечує можливість ураховувати інтереси, нахили і здібності кожного студента. Отже, особистісно зорієнтоване навчання передбачає врахування індивідуальних особливостей студентів, їхніх особистісних інтересів та можливостей.

Вивчення проблеми показало, що формування конкурентоздатності буде відбуватися більш ефективно, якщо: визначена сутність i структура конкурентоздатності випускника вищого навчального закладу; розроблена й запроваджена в освітній процес науково обгрунтована педагогічна модель формування конкурентоздатності майбутніх фахівців; розроблена система педагогічного впливу на студентів задля формування у них ключових компетенцій особистості, що зумовлюють позитивну динаміку процесу формування конкурентоздатності.

Задля підвищення ефективності комплексу організаційно-педагогічних умов для формування конкурентоздатності студентів можуть бути визначені такі шляхи, як: фіксація соціального замовлення суспільства на визначений рівень підготовки майбутніх фахівців; виявлення специфіки навчально-виховного процесу вищої професійної школи; виявлення суті конкурентоздатності студентів; системнофункціональна характеристика професійної підготовки майбутніх фахівців; виявлення чинників, які сприяють формуванню конкурентоздатності студентів; уведення в освітній процес вишів інновацій задля засвоєння їх змісту студентами; вивчення можливостей системного й особистісно-професійного підходів для процесу формування конкурентоздатності студентів.

Заслуговує на увагу дослідження В. Андреєва, який робить висновок, що становлення конкурентоздатної особистості буде ефективним, якщо: досягається гарантована якість освіти через творчий саморозвиток і самореалізацію; учень здійснює неперервний творчий саморозвиток, самореалізацію і самовизначення того виду діяльності, де прагне досягти вершини свого успіху; учень демонструє працелюбність і прагнення до якості кінцевого продукту своєї навчальної i 
професійно-творчої діяльності; у процесі навчання професійно-творчі особистісні якості педагога як конкурентоздатної особистості трансформуються в особистісні якості учнів; розвиток і саморозвиток лідерських якостей є однією із важливих умов становлення особистості; розглядати конкурентоздатність людини як багатомірне і багатофакторне явище; у процесі самооцінки, самодіагностики особистісних якостей активно стимулюється творча рефлексія [1]. Дещо інший підхід до визначення сутності і змісту організаційно-педагогічних умов формування конкурентоздатності обгрунтовує О.Гришин, який до таких умов відносить: активізацію усіх видів діяльності спеціалістів як компонента процесу професійної підготовки студентів на основі виявлених інтересів, схильностей, здібностей; використання особистіснопрофесійної рефлексії як чинника розвитку конкурентоздатності фахівця; організацію соціального партнерства спеціалістів і студентів на основі комплексу видів діяльності в процесі професійної підготовки; реалізацію концептуально-методичної моделі процесу професійної підготовки, орієнтованої на розвиток конкурентоздатності фахівця.

Стосовно нашого предмету дослідження, вважаємо за необхідне зазначити, що у професійній діяльності електромеханіка зустрічаються різні види неполадок та несправностей, причому одні зустрічаються часто, а інші - досить рідко, що потребує від фахівця не тільки знання алгоритму визначення традиційних несправностей i неполадок, а й, у нестандартних ситуаціях, бути здатним творчо підійти до справи, оскільки для розв'язання таких ситуацій немає ані заздалегідь відомих дій, ані готових алгоритмів знаходження рішення. Як стверджує О. Тарасова, «це вказує на необхідність постійної готовності робітника до інтелектуальної діяльності, яка дозволяє передбачити можливості аварій в екстремальних умовах гірничого виробництва» [7, с. 50]. Тому, продовжує далі науковець, найважливішою особливістю мислення практика $є$ необхідність самостійного виділення проблемних ситуацій у потоці діяльності. «Саме їх виникнення, - зазначає В. Чебишева, робітник повинен помітити, спостерігаючи за перебігом робочого процесу» [9, с. 223].

Як показує практика, у роботі електромеханіка важливо вміти грамотно читати креслення й уявляти на його основі реальний предмет. Технологічна карта для досвідченого фахівця $\epsilon$ інструкцією, яка дає йому основні відомості про характер завдання і засоби його виконання [7, с. 49]. Як зазначає Н. Менчинська, «...схема об'єднує ознаки конкретного та абстрактного мислення, оскільки вона сама наочно подана у просторі (тим самим є об'єктом зорового сприйняття) і водночас уособлює в умовній формі наявні відношення, які абстраговані від відношень реальних предметів» [6, с. 185]. Технологічно обміркувати креслення означає не тільки вміти уявити форму і пропорції зображеного на ньому механізму, а й вміти використати дані креслення для розв'язання конкретних виробничих завдань. Успішне розв'язання цих завдань залежить від сформованості у робітника просторових уявлень та творчого технічного мислення.

Отже, науковий аналіз проблеми формування конкурентоздатності майбутніх фахівців передбачає визначення низки педагогічних умов, які нададуть змогу ефективно побудувати навчально-виховний процес підготовки майбутніх конкурентоздатних на ринку праці електромеханіків.

Отже, ми передбачаємо, що формування конкурентоздатності студентів у процесі вивчення фахових дисциплін буде відбуватися більш ефективно за таких умов: упровадження особистісно зорієнтованого навчання під час вивчення фахових дисциплін; активізації пізнавальної і практичної діяльності на основі виявлених інтересів, схильностей, здібностей студентів; розвитку творчого технічного мислення 
студентів; розроблення та впровадження моделі формування конкурентоздатності майбутніх електромеханіків у процесі вивчення фахових дисциплін.

\section{Література}

1. Андреев В. И. Конкурентология : [учебный курс для творческого развития конкурентоспособности] / В. И. Андреев. - Казань : Центр инновац. технологий, 2004. - 468 с. 2. Бодьян Л. А. Развитие конкурентоспособности студентов технического вуза на основе контекстно-модульного похода: автореф. дис. на соискание ученой степени канд. пед. наук: спец. 13.00.08 «Теория и методика профессионального образования»/ Л. А. Бодьян. - Магнитогорск, 2009. - 22 с. 3. Завацька Л. А. Формування конкурентоспроможності фахівців галузі фізичної культури і спорту у вищих навчальних закладах недержавної форми власності/ Л. А. Завацька, Ж. Г. Сотник, О. С. Ільків // Проблеми фізичного виховання і спорту. 2011. - № 2. - С. 39-44. 4. Максимова О. Г. Система профессиональной ориентации школьников в условиях дифференцированного обучения / О. Г. Максимова // Проспект педагогических идей : сб. науч. трудов/ РАО, НИИ педагогики.Чебоксары, $\quad$ 1997. - С. 63-65. 5. Мезинов В. Н. конкурентоспособности будущего учителя в образовательном процессе университета: автореф. дис. на соискание ученой степени докт. пед. наук: спец. 13.00 .08 «Теория и методика профессионального образования» / В. Н. Мезинов. - Елец, 2009. - 43 с. 6. Менчинская Н. А. Проблемы учения и умственного развития школьника / Н. А. Менчинская. - М. : Педагогика, 1989. - 224 с. 7. Тарасова О. В. Психологічні умови розвитку професійного мислення учнів професійно-технічних навчальних закладів гірничого профілю: дис. ... канд. псих. наук : 19.00.07 / Тарасова Олена Володимирівна. - Київ, 2010. - 176 с. 8. Философский словарь / под ред. И. Т. Фролова. - [5-е изд.] - М. : Политиздат, 1986. - 590 с. 9. Чебышева В. В. Психология трудового обучения / В. В. Чебышева. - М. : Просвещение, 1969. - 303 с.

\section{ПІДГОТОВКА МАЙБУТНЬОГО ВЧИТЕЛЯ ПОЧАТКОВИХ КЛАСІВ ДО ПАТРІОТИЧНОГО ВИХОВАННЯ В УМОВАХ ОНОВЛЕННЯ ПОЧАТКОВОЇ ОСВІТИ}

Філімонова Т. В. Підготовка майбутнього вчителя початкових класів до патріотичного виховання в умовах оновлення початкової освіти.

У статті висвітлено теоретично обгрунтовані питання підготовки майбутніх учителів початкових класів до патріотичного виховання учнів в умовах оновлення початкової освіти. Розглянуто сутність поняття «підготовка майбутніх учителів початкових класів до патріотичного виховання учнів».

Ключові слова: майбутні вчителі, патріотична підготовка, патріотичне виховання, патріотична освіта.

Філімонова Т. В. Подготовка будущего учителя начальных классов к патриотическому воспитанию в условиях обновления начального образования.

В статье освещены теоретически обоснованные вопросы подготовки будущих учителей начальных классов патриотического воспитанию учеников в условиях обновления начального образования. Рассмотрена сущность понятия «подготовка будущих учителей начальных классов к патриотическому воспитанию учеников».

Ключевые слова: будущие учителя, патриотическая подготовка, патриотическое 